East African Journal of Science, Technology and Innovation, Vol. 1 (3): 2020.

This article is licensed under a Creative Commons license, Attribution 4.0 International (CC BY 4.0)

\title{
Impact of calf feeding practices on calf growth and health in smallholder dairy farms in Nyeri County, Kenya
}

\author{
1*SITUMA SN., 2 GITAU GK., ${ }^{3}$ VANLEEUWEN J., 2 MULEI CM., 2 KIMELI P
}

\author{
${ }^{1}$ Department of Animal Science, School of Agricultural Sciences and Agribusiness, Pwani University, P.O Box 195-80108-Kilifi. \\ ${ }^{2}$ Department of Clinical Studies, Faculty of Veterinary Medicine University of Nairobi P.O Box 29053- 00625- Nairobi. \\ ${ }^{3}$ Department of Health Management, Atlantic Veterinary College University of Prince Edward Island 550 University Avenue, \\ Charlottetown, PE C1A 4P3, Canada \\ *Corresponding author: nafsitu@gmail.com
}

\begin{abstract}
The objective of this study was to assess potential impact of selected enhanced feeding practices on growth of smallholder dairy calves. In the period between May and August 2012, 36 privately owned Kenyan smallholder dairy farms with new-born calves were purposively selected to participate in a randomized control trial. The calves were randomly allocated to one of nine feed intervention groups based on three groups of Calf Starter Intake (CSI; 20\% protein) and three groups of Milk Intake (MI): control, half, and full. Full CSI intake involved lead feeding to achieve up to $1 \mathrm{~kg} /$ day feed intake at weaning, half CSI was to maximize intake at $0.5 \mathrm{~kg} /$ day at weaning, while control CSI was the farmers' normal practice (0-0.2 kg/day). Full MI was 4 Liters/day and half milk intake was 2 Liters/day, while control MI was the farmers' normal practice (2-10 Liters/day). Each of the nine intervention groups had four calves per group (one calf died during the 1st week) resulting in 35 calves. Data on calf weight and height were collected weekly through farm visits for a period of eight weeks, and management data were collected through an in-person questionnaire. The results showed significant differences in the mean average daily weight gains across the different feed intervention groups at $\mathrm{P}(<0.001)$. All full CSI groups had weight gains over $0.5 \mathrm{~kg} /$ day. The full CSI + control MI had a positive association with the mean average daily weight gain at $(0.61 \mathrm{~kg} /$ day), higher than the other two full CSI groups because of higher MI in this small group. In mixed multivariable linear regression analyses, weekly calf weights were higher with calf age and body condition score, a normal gastrointestinal tract, and amount of calf starter consumed per day, along with feeding sweet potato vines.
\end{abstract}

Keywords: Average daily gain; calf starter; calves; milk intake; Smallholder dairy

Cite as: Situma, 2020 Impact of calf feeding practices on calf growth and health in smallholder dairy farms in Nyeri County, Kenya. East African Journal of Science, Technology and Innovation 1(3)
Received: $\quad$ 06/06/19

Accepted: $\quad 21 / 02 / 20$

Published: $\quad 24 / 06 / 20$ 


\section{Introduction}

To achieve a sustainable dairy production system, good herd management is of great importance (Chang'a, et al., 2011). The Kenyan dairy industry is the second largest in Africa after South Africa, based on the number of people it employs, heads of dairy cattle and amount of milk produced (Oloo, 2016). Kenya has an estimated population of 1.7 million dairy farmers with average herd size of 4 cows (Oloo, 2016). Although Kenya holds a central position in Africa's smallholder dairy industry, there is still evidence of under-production on individual smallholder dairy farms (Wambugu et al., 2011).

Smallholder dairy farmers tend to underfeed the young stock as they are usually more interested in selling milk for an income than investing in the maintenance of a new-born calf, more so if the calf is a bull (Listiari et al., 2015). This underfeeding is primarily attributed to the time span that the young stock have between any financial investments and returns while on the farm (Listiari et al., 2015; Moran, 2009; Tiwari et al., 2007). Even though this is the case with smallholder dairy farmers, it is evident that the general profitability of a calf rearing enterprise is highly dependent on adequate and appropriate nutrition for calf health and optimal growth (Chang'a, et al., 2011; Lanyasunya et al., 2006).

The natural pastures, tropical grasses and/or home-grown fodders used by smallholder dairy farmers in the tropics for forage often have low protein, carbohydrate, and mineral content as a result of late harvest and inappropriate storage (Chang'a et al., 2010; Njarui et al., 2011). High fiber and low nutrient content of the forages impact negatively on their digestibility and overall quality (Chang'a et al., 2010; Njarui et al., 2011). In sub-Saharan Africa, farmers are further limited by their lack of knowledge with regard to good animal husbandry and farm management practices that could ensure provision of appropriate and adequate nutrition to the dairy calves (Gitau et al., 1994; VanLeeuwen et al., 2012; Nyka et al., 2014).

In Kenya, inadequate nutrition in smallholder dairy calves has been attributed to insufficient knowledge among farmers on best nutritional practices (Gitau et al., 1994, Peter et al., 2015; Peter et al., 2016). Failure to feed adequate milk volumes, introduce calf starter early, and store forage suitably, along with the lack of data on the costs and benefits attributed to these practices within the context of their management systems, have greatly contributed to improper nutrition among smallholder dairy calves (Gitau et al., 1994, Peter et al., 2015; Peter et al., 2016).

Poor feeding practices in smallholder dairy calves contribute to delay in initiation of rumen development (Fernández et al., 2012). In addition, challenges of planting limitations, feeding and/or storage of locally appropriate, highprotein forages for dairy calves impact on the birth weights and heights for their age, (Peter et al., 2015; Peter et al., 2016).

Richards et al. (2015) ascribes the difficulty of developing locally appropriate feeding practices for farmers in Kenya to limited field-based research and recommendations on the effect of cattle feeding interventions on smallholder farms. Smallholder dairy farmers are further disadvantaged because there is lack of evidencebased data that can be used to create awareness of the possible long-term implications of poorly reared young stock; hence, they often tend to shift their attention away from their calf-rearing systems (Moran, 2005). In this regard, the objective of this trial was to document the potential impact of selected enhanced feeding practices translated as recommended amounts of calf starter and milk on the health and growth of dairy calves reared under smallholder systems.

\section{Materials and methods}

\section{Study site}

The study was carried out in Mukurwe-ini Subcounty of Nyeri County, Kenya, with members of the Mukurwe-ini Wakulima Dairy Limited (MWDL) from May-August 2012. Mukurwe-ini has an estimated population of 89,137 people as of 2018 and covers $179 \mathrm{~km}^{2}$ (Kenya National Bureau of Statistics, 2019). The study area is considered part of the humid highlands at an altitude of over $1500 \mathrm{~m}$, with annual rainfall over $1000 \mathrm{~mm}$ and humidity $>50 \%$ (Orodho, 2006). 
This area is classified as an agro-climatic zone (IIII) that has a high potential for growing crops (Orodho, 2006).

\section{Study population}

The target population of the study consisted of smallholder dairy farmers in Mukurwe-ini Subcounty of Nyeri County. The 36 study farms were selected purposively based on MWDL records of artificial insemination (AI) that projected farms that were likely to have a new-born calf $(<1$ week old) on the farm by the beginning of the study period, as well as the farmers' willingness to participate in the study. Other important factors of selection of the farms were that each of the homesteads had to have not more than 4 animals and belong to MWDL in order to be enrolled. The coordinator of MWDL provided a list of eligible active members to facilitate this process. The 36 smallholder dairy farms with Holstein-Friesian cattle represented a broad cross-section of the MWDL members.

\section{Study design}

The study design was a randomized controlled field trial with a total population of 36 new-born calves recruited. The calves were randomly allocated to nine feed intervention groups of 4 calves each (a $3 \times 3$ factorial feeding design ), and an identification tag was placed on the left ear of each study calf. The nine feeding groups assigned were based on three possible groups of Calf Starter Intake (CSI) and three possible groups of Milk Intake (MI). Full calf starter intake (20\% protein) was defined as providing the farmers with calf starter for lead feeding to achieve up to $1 \mathrm{~kg} /$ day at weaning at 2 months of age, half calf starter intake was to achieve intakes up to 0.5 $\mathrm{kg} /$ day at weaning at 2 months of age, while control calf starter intake was whatever calf starter intake the farmer normally offered (ranged from 0-0.2 kg/day). Appropriate amounts of free calf starter were provided to the full and half CSI farms but no free calf starter was provided by the project to the farmers in the control CSI farms. Full milk intake was defined as paying farmers for 4 Liters/day to be fed to the calf; and half milk intake was paying farmers for 2 Liters/day, while control milk intake was whatever milk quantity the farmer normally offered. There were no milk payments for this group of farms, and milk consumption was recorded to range from 2-5 Liters/day.

Farms were visited weekly for a total of eight weeks to collect data and ensure the prescribed feeding regimen was being followed. On the second visit to one farm, a calf was reported to have died during the $1^{\text {st }}$ week of the study, after the recruitment period was over; therefore, no weight/height gain information could be obtained for that particular calf, and no replacement calf could be obtained, leaving 35 calves finishing the trial.

\section{Data collection}

Data were collected by a veterinarian and three trained veterinary students. The data collected during the study period included observational data from the selected farms, which included nutritional practices, animal demographics, and specific calf management practices during the trial. The demographic data and specific calf management data were collected using a questionnaire, and a translator was utilized to ensure ease of communication among study participants. The parameters evaluated included general animal health observations, body weight and height, and feed intake. The health status of the calves was determined by conducting a physical examination of the calf that included but not limited to; temperature, heart rate, respiratory rate, colour of mucous membranes, palpation of superficial lymph nodes, skin condition, and examination of the faeces, joints, feet and umbilicus. Any abnormalities observed were recorded and treated on the farm. The body height was measured using a tape measure from the withers to the ground at the foreleg heel, and weight was estimated by measuring the heart girth using a weigh band tape while calves were in a standing position. The heart girth obtained was then used to estimate the bodyweight using the following formula: Bodyweight $[\mathrm{kg}]=($ Heart girth [cm] - 67.07)/0.4 (Chang'a et al., 2010). Height and weight measurements were done on a weekly basis for a period of eight weeks at ages ranging from the first day of life to 60 days old. On each visit, the farmers were also asked to recall their calf feeding management of the previous day (i.e. how water was offered (always available or sometimes available), and the amounts of calf starter, forages, mineral and milk fed. 


\section{Statistical analysis}

The data were stored in Excel (Microsoft Corporation, 2010) and analysed using SAS (Statistical Analytical Software, version 9.1.3 portable, 2006). Descriptive statistics for weight and height were determined using the means procedure in SAS (version 9.1.3 portable, 2006). Observed data lines/curves were plotted to help visualize the increases in mean weekly weights and heights for each feed group over the various time points. Differences in average weekly heights and weights among the groups were subjected to analysis of variance (ANOVA) at $p \leq 0.0 .5$. Significant differences among group means were separated using Least Significant Difference (LSD) at 95\% confidence level. Posthoc Bonferroni test adjustment was used to account for the multiple comparisons between groups.

Data on weekly weight and height of the calves were converted to average daily gain (ADG) in weight or height overall for each group. These data were graphed by intervention group for additional visualization of the trial data.
The recorded weekly weight data were assessed for normality using the Shapiro-Wilk test, and Box-Cox analysis was conducted to identify a suitable transformation for weekly weight to allow us to determine factors associated with weekly weights. Univariable mixed linear regression models for all of the predictor variables (with animal as a random effect) were fitted in separate models initially, and those variables having $p<0.30$ were retained for subsequent analyses. Mixed multivariable regression analysis was subsequently utilized, controlling for confounding of other variables in the model. Backward elimination continued until all remaining model variables were significant at $\mathrm{p}<0.05$, or were confounders. Significant twoway interactions between significant variables in the final model were assessed and retained if $p<0.05$. Model residuals were examined for evidence of model goodness of fit.

\section{Results}

A summary of the farm-level demographics of the 35 smallholder dairy farms is shown in Table 1 .

Table 1: Farm-level demographics of the farmers of 35 smallholder dairy farms in Nyeri County, Kenya, 2012

\begin{tabular}{|c|c|c|c|}
\hline Categorical variable & Category & Number & Proportion (\%) \\
\hline \multirow[t]{2}{*}{ Respondent's sex } & Female & 12 & 34.3 \\
\hline & Male & 23 & 65.7 \\
\hline \multirow[t]{3}{*}{ Marital status } & Married & 32 & 91.4 \\
\hline & Widowed & 2 & 5.7 \\
\hline & Single & 1 & 2.9 \\
\hline \multirow[t]{3}{*}{ Household size } & $<=2$ persons & 10 & 28.6 \\
\hline & 3-5 persons & 20 & 57.1 \\
\hline & $>5$ persons & 5 & 14.3 \\
\hline \multirow[t]{4}{*}{ Education status } & College & 1 & 2.9 \\
\hline & Secondary & 20 & 57.1 \\
\hline & Primary & 13 & 37.1 \\
\hline & Non-formal & 1 & 2.9 \\
\hline \multirow{3}{*}{$\begin{array}{l}\text { Dairy } \\
\text { experience }\end{array}$} & 1-3 years & 4 & 11.4 \\
\hline & $4-9$ years & 12 & 34.3 \\
\hline & $>10$ years & 19 & 54.3 \\
\hline \multirow{3}{*}{$\begin{array}{lcc}\text { Percent } & \text { of } & \text { yearly } \\
\text { income } & \text { from } & \text { dairy } \\
\text { farming } & & \end{array}$} & $<50 \%$ & 17 & 48.6 \\
\hline & $50-70 \%$ & 14 & 40.0 \\
\hline & $>70 \%$ & 4 & 11.4 \\
\hline
\end{tabular}


On the farms, $65.7 \%$ of the respondents were male and most of owners were married $(91.4 \%)$, with at least $57.1 \%$ having attained secondary school education. Over half $(54.3 \%)$ of the farmers had over 10 years of dairy experience, and $51.4 \%$ earned over $50 \%$ of their total income from dairy cattle farming. The households had an average of 3-5 persons. There were no significant differences in any of these demographic parameters among the study groups.

The compliance of the farmers to feed what was recommended for their calf group was less than ideal, but since these were privately owned animals, the recommendations were only meant to be guidelines. The control MI groups fed more milk on average (5.6-5.7 Liters/day) than all other groups (4.7-5.4 Liters/ day) except Group 2 (5.67 Liters/day). Conversely, the compliance was somewhat better for the recommended calf starter feeding. While the full CSI groups consumed over $0.6 \mathrm{~kg} /$ day of calf starter on average, the control and half CSI groups consumed 0.1-0.3 and 0.3-0.4 of calf starter on average, respectively. Ranges of milk and calf starter feeding were 2-10 Liters/day and 0-1.0 $\mathrm{kg} /$ day, respectively.

There were $40.6 \%$ heifers in the final dataset of calves. Weights and heights ranged between 38 and $89 \mathrm{~kg}$, and between 67 and $94 \mathrm{~cm}$, respectively. Figure 1 shows the mean weights at each week during the study across the feed intervention groups. The full CSI + control MI group (Group 7) recorded the highest mean weights at the start and end of the trial and all weeks in between except week 3, while the half CSI and half MI group (Group 5) recorded the lowest mean weights at 6 of the 9 time points of the study period.

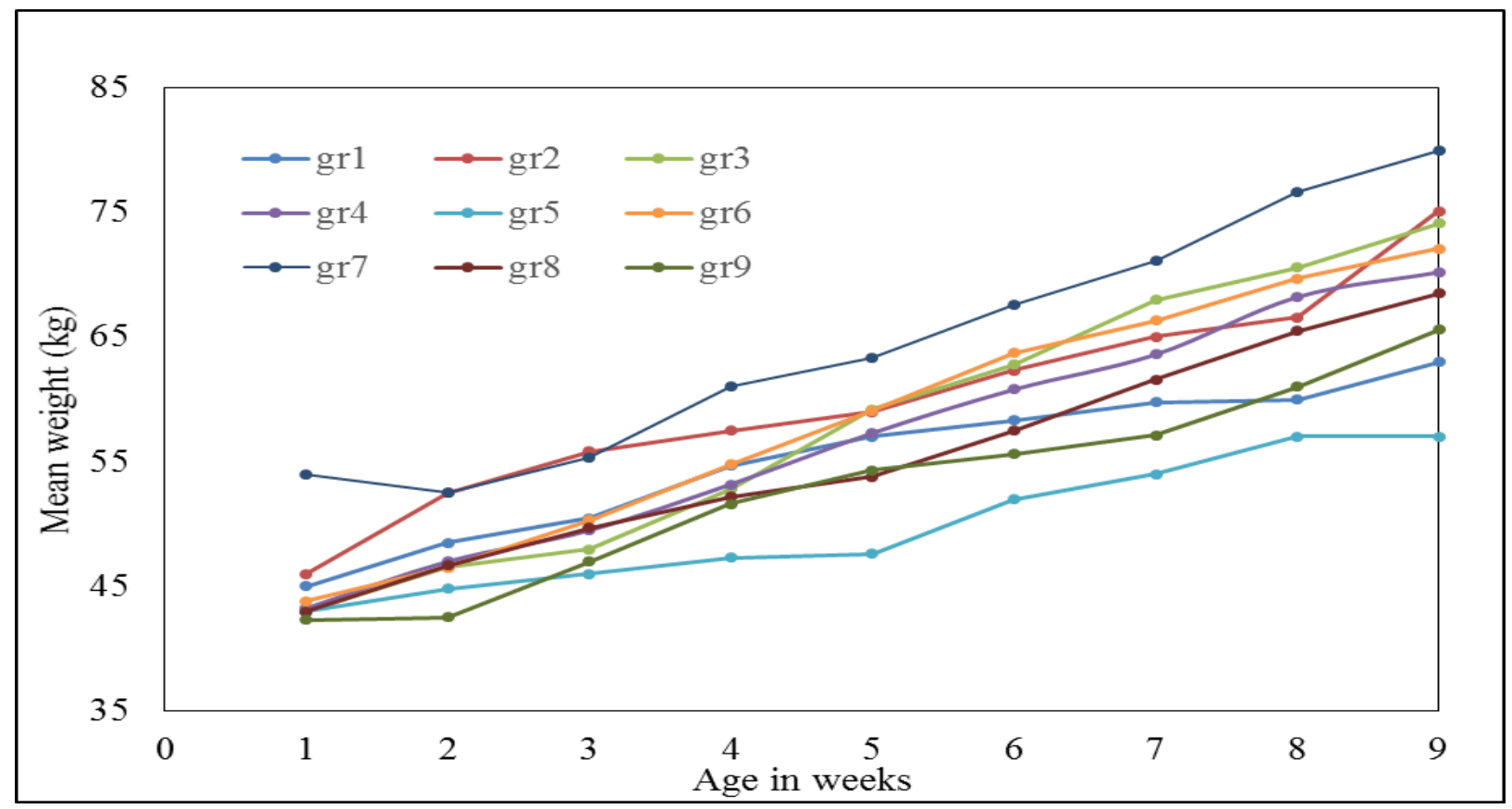

Figure 1: Mean weight $(\mathrm{kg})$ by age in weeks for 35 calves across the nine feed intervention groups in 35 smallholder dairy farms in Nyeri County, Kenya, 2012.

KEY:

Gr $1=$ Control Calf Starter + Control Milk Intake Gr 2 =Control Calf Starter + Half Milk Intake Gr 3 = Control Calf Starter + Full Milk Intake Gr 4 = Half Calf Starter +Control Milk Intake
Gr 5 = Half Calf Starter + Half Milk Intake Gr $6=$ Half Calf Starter + Full Milk Intake Gr $7=$ Full Calf Starter + Control Milk Intake Gr $8=$ Full Calf Starter + Half Milk Intake Gr $9=$ Full Calf Starter+ Full Milk Intake 
Table 2, after post-hoc Bonferroni adjustments, revealed significant differences in average weekly weights between feed intervention groups 5 (half CSI + half MI - $49.94 \mathrm{~kg}$ ) and 7 (full CSI + control MI $-64.65 \mathrm{~kg}$ ) with the rest of the feed intervention groups at $p<0.05$. Significant differences between groups are demonstrated by different letter superscripts in the table.

Table 2: Post-hoc Bonferroni-adjusted test results for mean weight $(\mathrm{kg})$ for 35 smallholder dairy calves across nine feed interventions in farms in Nyeri County, Kenya, 2012

\begin{tabular}{llll}
\hline Feed intervention group & $\begin{array}{l}\text { Mean } \\
\text { weekly } \\
\text { weight }\end{array}$ & SEM & SD \\
& $49.94^{\mathrm{a}}$ & 1.54 & 8.02 \\
\hline Half calf starter + Half milk intake (Grp 5) & $52.73^{\mathrm{ab}}$ & 1.80 & 9.53 \\
Full calf starter + Full milk intake (Grp 9) & $53.93^{\mathrm{ab}}$ & 1.44 & 8.64 \\
Half calf starter +Control milk intake (Grp 4) & $56.01^{\mathrm{abc}}$ & 1.72 & 10.19 \\
Control calf starter + Control milk intake (Grp 1) & $56.15^{\mathrm{abcd}}$ & 1.46 & 8.54 \\
Full calf starter + Half milk intake (Grp 8) & $57.98^{\mathrm{abcd}}$ & 1.93 & 11.09 \\
Control calf starter + Full milk intake (Grp 3) & $59.11^{\mathrm{bcd}}$ & 1.92 & 11.05 \\
Control calf starter + Half milk intake (Grp 2) & $62.09^{\mathrm{cd}}$ & 2.08 & 12.31 \\
Half calf starter +Full milk intake (Grp 6) & $64.65^{\mathrm{d}}$ & 2.17 & 11.07 \\
\hline Full calf starter + control milk intake (Grp 7) & & & \\
\hline
\end{tabular}

Figure 2 shows the mean heights at each week during the study across the feed intervention groups. Intervention group 7 (full CSI + control MI) recorded the highest mean height throughout the study. Feed intervention group 5 (half CSI + half MI) recorded the lowest mean height on 7 of 9 weeks of the study.

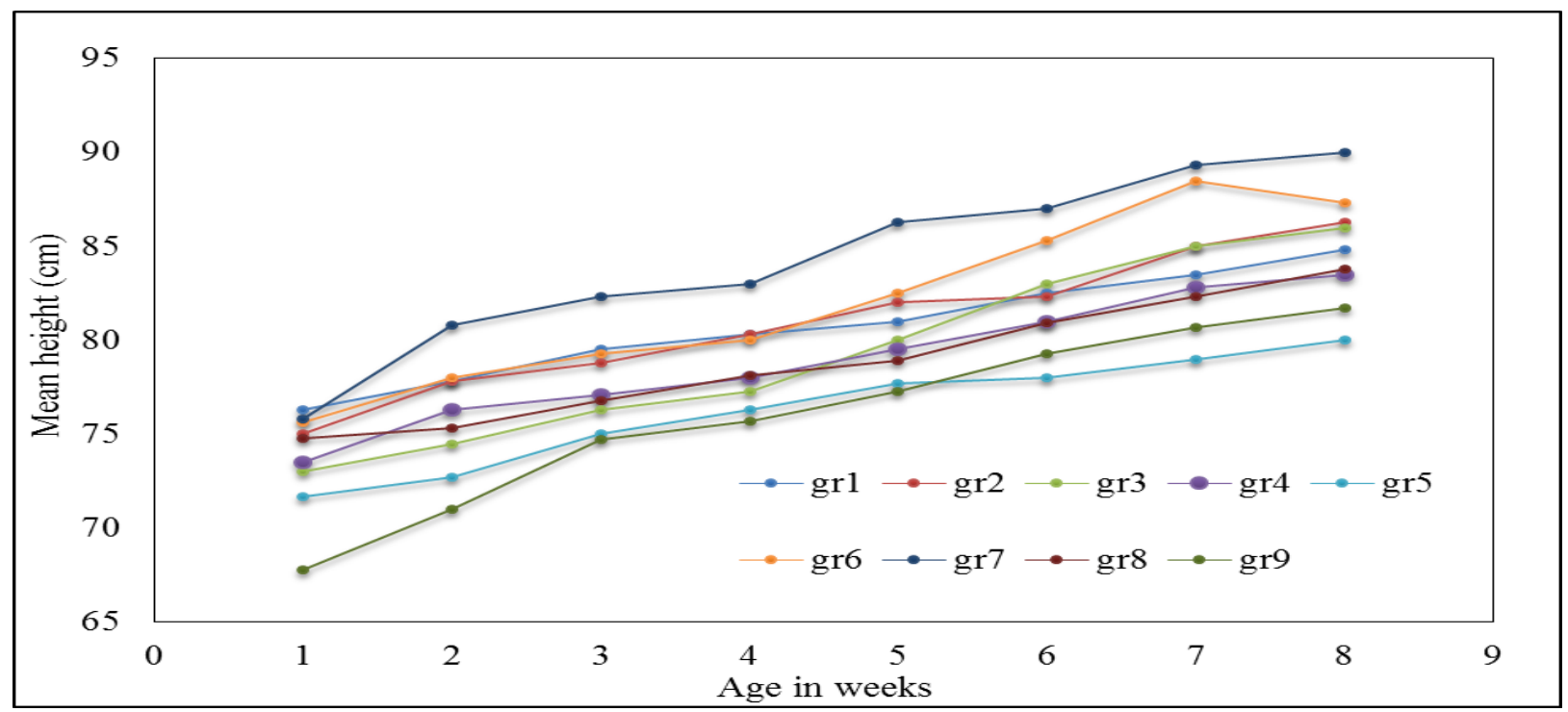

Figure 2: Mean height $(\mathrm{cm})$ by age in weeks for 35 calves across the nine feed intervention groups in 35 smallholder dairy farms in Nyeri County, Kenya, 2012.

KEY

Gr 1 = Control Calf Starter + Control Milk Intake

Gr 2 =Control Calf Starter + Half Milk Intake

Gr 3 = Control Calf Starter + Full Milk Intake

Gr 4 = Half Calf Starter +Control Milk Intake

Gr 5 = Half Calf Starter + Half Milk Intake
Gr 6 = Half Calf Starter + Full Milk Intake

Gr $7=$ Full Calf Starter + Control Milk Intake

Gr $8=$ Full Calf Starter + Half Milk Intake

Gr $9=$ Full Calf Starter+ Full Milk Intake 
Table 3, after post-hoc Bonferroni adjustments, revealed significant differences in average weekly heights between feed intervention groups 5 (half CSI + half MI $-75.59 \mathrm{~cm}$ ) and 7 (full CSI + control MI $-84.17 \mathrm{~cm}$ ) with the rest of the feed intervention groups at $p<0.05$. Again, individual differences between groups are demonstrated by different letter superscripts in the table.

Table 3: Post-hoc Bonferroni-adjusted test results for mean height $(\mathrm{cm})$ for 35 smallholder dairy calves across nine feed interventions in farms in Nyeri County, Kenya, 2012

\begin{tabular}{|c|c|c|c|}
\hline Feed intervention group & $\begin{array}{l}\text { Mean weekly } \\
\text { height }\end{array}$ & SEM & SD \\
\hline Half calf starter + Half milk intake (Grp 5) & $75.59^{a}$ & 0.97 & 5.06 \\
\hline Full calf starter + Full milk intake (Grp 9) & $76.29 \mathrm{ab}$ & 1.23 & 6.49 \\
\hline Half calf starter +Control milk intake (Grp 4) & $78.03^{\mathrm{abc}}$ & 0.87 & 5.24 \\
\hline Control calf starter + Control milk intake (Grp 1) & $78.66^{\mathrm{abc}}$ & 0.85 & 4.98 \\
\hline Full calf starter + Half milk intake (Grp 8) & $78.94^{\mathrm{abc}}$ & 1.06 & 6.06 \\
\hline Control calf starter + Full milk intake(Grp 3) & $79.97 \mathrm{abcd}$ & 0.78 & 4.62 \\
\hline Control calf starter + Half milk intake (Grp 2) & $80.17 \mathrm{bcd}$ & 0.83 & 4.75 \\
\hline Half calf starter + Full milk intake (Grp 6) & $81.43^{\mathrm{cd}}$ & 1.00 & 5.94 \\
\hline Full calf starter + Control milk intake (Grp 7) & $84.17^{d}$ & 1.13 & 5.75 \\
\hline
\end{tabular}

Figure 3 shows the mean weights of calves being fed or not fed various dietary supplements (other than milk and calf starter), along with the number and \% of calves feeding on these supplements. From this description that does not take into account intervention group, Napier, other grasses (Rhodes grass (Chloris gayana) and Kikuyu grass (Pennisetum clandestinum) and sweet potato vines were commonly fed supplements, while banana leaves and minerals were not commonly fed. Water was always available on $77.1 \%$ of the smallholder farms

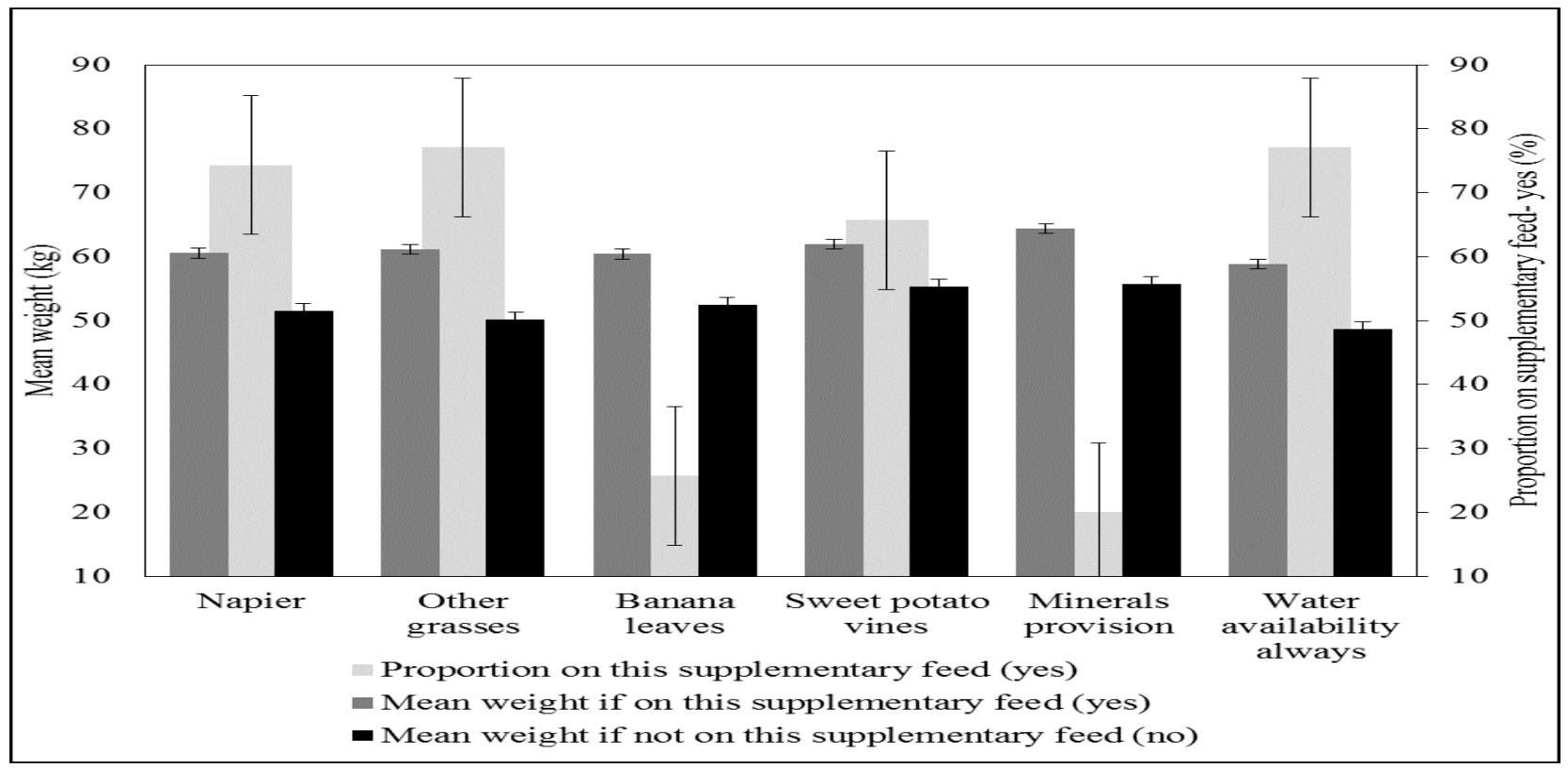

Figure 3. Proportion of supplementary feeding and mean weights, by supplemental feeding (yes/no), of 35 smallholder dairy farms in Nyeri County, Kenya, 2012. 
Figure 4 shows the ADG in weight and height, by intervention group, over the entire study period. The overall average ADG was $0.47 \mathrm{~kg} /$ day. Calves on full CSI (groups 7-9, getting up to $1 \mathrm{~kg} /$ day of starter) were able to achieve ADG in weight of at least $0.5 \mathrm{~kg} /$ day. Group 5 had an ADG in weight below 0.3 $\mathrm{kg}$ / day, showing substantial variation in ADG of weight. ADG in height had less variation among groups.

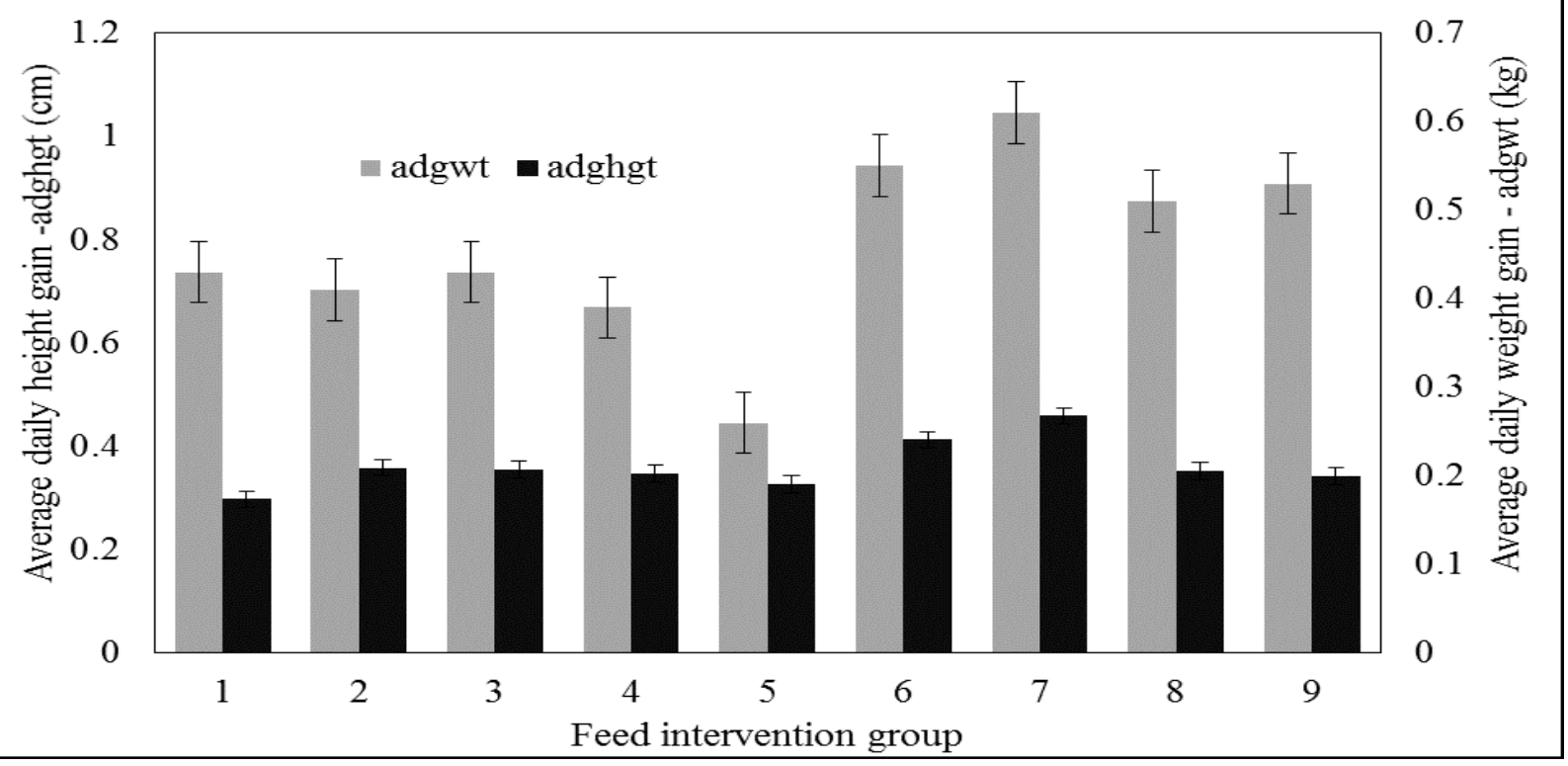

Figure 4: Average daily gain in weight $(\mathrm{kg})$ and height $(\mathrm{cm})$ by feed intervention groups, of 35 smallholder dairy farms in Nyeri County, Kenya, 2012.

KEY:

Gr 1 = Control Calf Starter + Control Milk Intake

Gr 2 =Control Calf Starter + Half Milk Intake

Gr 3 = Control Calf Starter + Full Milk Intake

Gr 4 = Half Calf Starter +Control Milk Intake

During the study period, $17.1 \%(6 / 35)$ of the calves were diagnosed with a disease; they included diarrhoea and pneumonia at $11.4 \%$ $(4 / 35)$ and $5.7 \%(2 / 35)$, respectively. During the study $5.7 \%(2 / 35)$ of the calves died, and no cause of death was available. The calves that got sick were from intervention groups 1, 2, 4, 5, 6 and 8 , while the two calves that died were from intervention groups 9 and 7. One calf in Group 5 was sick for 3 weeks in a row, while the other sick calves were only sick for one week, likely contributing to the low weights of that group.

Table 4 shows univariable mixed linear regression associations with inverse of weekly weights, the best Box-Cox transformation to
Gr $5=$ Half Calf Starter + Half Milk Intake

Gr 6 = Half Calf Starter + Full Milk Intake

Gr $7=$ Full Calf Starter + Control Milk Intake

Gr $8=$ Full Calf Starter + Half Milk Intake

Gr 9 = Full Calf Starter+ Full Milk Intake

make the weekly weight data normally distributed. The findings demonstrated positive significant association between inverse weight and amount of milk fed. Conversely, the following farm-level variables were negatively associated with inverse weight: farm size, amount of calf starter consumed, supplementary feeding of other grasses, sweet potato vines, banana leaves and a mineral block, water provision (always), separate housing (versus group housing), and pen score $(0=$ poor; 1 =fair; $2=$ good). The sex of the calf and her dam parity also had significant negative animal-level associations with the inverse weights among the smallholder dairy calves. Significant visit-level 
variables negatively associated with inverse weight included calf age and body condition score, and that the calf had a normal cardiopulmonary system and gastrointestinal tract. Intervention group was also significantly associated with inverse weight.

Global $p$ value for whole variable (Table 5) shows final multivariable mixed linear regression model findings. The results demonstrated a significant negative association between inverse weight and increasing age and higher body score, amount of calf starter consumed per day, and normal function of the gastrointestinal tract. Interpretation of these coefficients requires a conversion. For example, each additional day of calf age (coefficient of -0.001384 ) was associated with a $0.41 \mathrm{~kg}$ increase in weight, assuming a median weight of $54.50 \mathrm{~kg}$ (inverse of 0.0183486 ), based on the calculation of 1/0.0183486 less $1 / 0.001384=0.41$. Similar calculations can be done for the other model coefficients of variables mentioned above: each additional $\mathrm{kg}$ of calf starter consumed per day and each additional point of body condition score were associated with increases of $2.3 \mathrm{~kg}$ and $1.9 \mathrm{~kg}$ above the median weight, respectively. A normal gastrointestinal tract was associated with an increase of $1.9 \mathrm{~kg}$ above the median weight.

There was also a significant interaction between supplementary feeding of sweet potato vines and provision of mineral blocks, as demonstrated in Figure 5. Feeding of sweet potato vines, regardless of whether mineral was fed or not, resulted in higher weights among the smallholder dairy calves $(55.2 \mathrm{~kg})$. However, failure to feed sweet potato vines resulted in significantly lower weights among the calves, at $54.0 \mathrm{~kg}$ when a mineral block was not fed, and as low as $50.9 \mathrm{~kg}$ when a mineral block was fed. Examination of model residuals demonstrated goodness of fit of the final model. Intervention group was not significant in the final model.

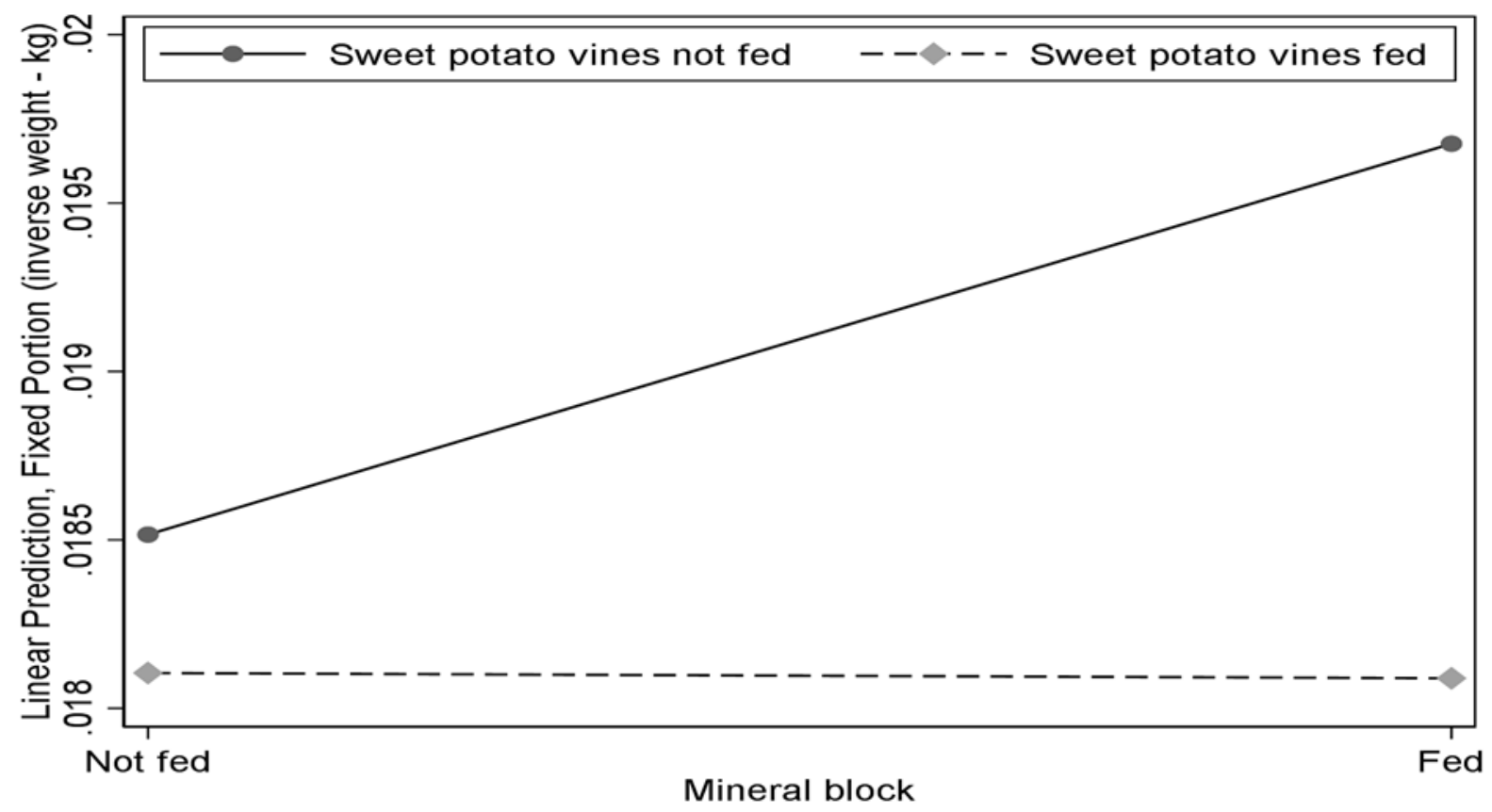

Figure 5: Predictive margins of the interaction variable formed from supplementary feeding of mineral blocks and sweet potato vines for 35 smallholder dairy calves in Nyeri County, Kenya, 
Table 4: Univariable mixed linear regression associations with inverse of weekly weights $(\mathrm{kg})$ in 35 Holstein Friesian pre-weaned calves in smallholder dairy farms of Nyeri County, Kenya, 2012

\begin{tabular}{|c|c|c|c|c|}
\hline Factors & Coefficient & $95 \% \mathrm{CI}$ & & P-value \\
\hline \multicolumn{5}{|l|}{ Farm-level factors $(\mathrm{n}=35)$} \\
\hline Farm size & -0.000748 & -0.001700 & 0.000204 & 0.124 \\
\hline Milk fed (Liters/day) & 0.000359 & 0.000075 & 0.000644 & 0.013 \\
\hline Calf pellets fed (kg/day) & -0.006365 & -0.007226 & -0.005503 & $<0.001$ \\
\hline Intervention group - Group 1 & Baseline & Baseline & & $0.002^{*}$ \\
\hline Group 2 & -0.000962 & -0.003229 & 0.001306 & 0.406 \\
\hline Group 3 & -0.000619 & -0.002718 & 0.001480 & 0.563 \\
\hline Group 4 & 0.000801 & -0.001297 & 0.002900 & 0.454 \\
\hline Group 5 & 0.002192 & -0.000076 & 0.004459 & 0.058 \\
\hline Group 6 & -0.001554 & -0.003653 & 0.000544 & 0.147 \\
\hline Group 7 & -0.002908 & -0.005175 & -0.000641 & 0.012 \\
\hline Group 8 & -0.000232 & -0.002331 & 0.001866 & 0.828 \\
\hline Group 9 & 0.000835 & -0.001432 & 0.003102 & 0.471 \\
\hline Other grasses (yes/no) & -0.003890 & -0.004401 & -0.003380 & $<0.001$ \\
\hline Sweet potato vines (yes/no) & -0.003272 & -0.003892 & -0.002652 & $<0.001$ \\
\hline Banana leaves (yes/no) & -0.002803 & -0.003678 & -0.001929 & $<0.001$ \\
\hline Mineral block (yes/no) & -0.003212 & -0.004265 & -0.002159 & $<0.001$ \\
\hline Water availability-always (yes/no) & -0.003797 & -0.004561 & -0.003033 & $<0.001$ \\
\hline Separate housing (yes/no) & -0.003578 & -0.005040 & -0.002116 & $<0.001$ \\
\hline Pen hygiene score - Score 0 & Baseline & Baseline & & $<0.001^{*}$ \\
\hline Score 1 & -0.00316 & -0.005105 & -0.001207 & 0.0 .002 \\
\hline Score 2 & -0.00500 & -0.006967 & -0.003031 & $<0.001$ \\
\hline \multicolumn{5}{|l|}{ Animal-level factors $(\mathrm{n}=35)$} \\
\hline Calf sex (heifer) & -0.000870 & -0.00226 & 0.000518 & 0.219 \\
\hline Dam parity & -0.000651 & -0.001681 & 0.000378 & 0.215 \\
\hline \multicolumn{5}{|l|}{ Visit-level factors $(\mathrm{n}=256)$} \\
\hline Calf age (days) & -0.000149 & -0.000156 & -0.000141 & $<0.001$ \\
\hline Calf body condition score & -0.002623 & -0.003352 & -0.001893 & $<0.001$ \\
\hline Calf cardiopulmonary system normal & -0.002082 & -0.003792 & -0.000372 & 0.017 \\
\hline Calf gastrointestinal tract normal & -0.002435 & -0.004117 & -0.000754 & 0.005 \\
\hline
\end{tabular}

Table 5: Final multivariable mixed linear regression model of associations with inverse of weekly weights $(\mathrm{kg})$ in 35 Holstein Friesian pre-weaned calves in smallholder dairy farms of Nyeri County, Kenya, 2012

\begin{tabular}{llll}
\hline Factor & Coefficient & $95 \%$ CI & P-value \\
\hline Farm-level factors & & & \\
Sweet potato vines fed & -0.0004107 & $-0.0007185-0.0000103$ & 0.009 \\
Mineral block fed & 0.0011605 & 0.00054640 .0017747 & $<0.001$ \\
Mineral block fed * Sweet potato vines fed & -0.0011763 & $-0.001856-0.0004966$ & 0.001 \\
Visit-level factors & & & \\
Calf pellets consumed (kg/day) & & & \\
Calf age (days) & -0.0006268 & $-0.0011815-0.0000721$ & 0.027 \\
Calf body condition score & -0.0001318 & $-0.0001424-0.0001212$ & $<0.001$ \\
Calf gastrointestinal tract normal (yes/no) & -0.0007471 & $-0.0010297-0.0004846$ & $<0.001$ \\
\hline
\end{tabular}




\section{Discussion}

This study demonstrated an overall mean average daily weight gain of $0.47 \mathrm{~kg} /$ day. This growth rate is higher than the earlier reported rates of $0.207 \mathrm{~kg} /$ day for up to five months of age in dairy calves raised in intensive systems in Kiambu County, Kenya (Gitau et al., 1994), and $0.36 \mathrm{~kg} /$ day for up to 6 months of age in Meru County, Kenya (Makau et al., 2019; Makau et al., 2018). Growth rates of $0.24 \mathrm{~kg} /$ day have been reported to result in late age at first calving in Kenya, averaging 41 months (Odima et al., 1994). The higher growth rates recorded in this study were likely due to the high protein intake, especially in the calf starter (20\%). This finding is consistent with a randomized study carried out in Tanzania on smallholder dairy calves that reported reasonably high growth rates of $(0.44$ $\mathrm{kg} /$ day) that were attributed to the high protein content $(19 \%)$ in the calf starter feed provided in that study (Lyimo et al., 2010). There were significant differences between weights and weight gains among the study groups (Figures 4). Calves on full CSI (up to $1 \mathrm{~kg}$ /day) were able to achieve average daily weight gains over 0.5 $\mathrm{kg} /$ day, and as high as $0.61 \mathrm{~kg} /$ day. These rates are within the ideal and recommended growth rates $(0.5-0.73 \mathrm{~kg} /$ day) suggested for smallholder dairy calves (Laswai et al., 2007; Lyimo et al., 2010). Calf starter was also a significant variable in the final model, leading to higher calf weights. Clearly, being in the full calf starter group, getting its high protein content $(20 \%)$, was important to their superior growth

Even though it was expected that full CSI + full MI (Group 9) would be superior to the rest of the feed interventions, this was not the case. The full CSI + control MI group (Group 7) had the highest mean ADG and it achieved the goal of daily consumption of up to $1 \mathrm{~kg} /$ day of CSI at the time of weaning at 2 months of age, with a milk consumption that ranged between 2 to 10 Liters/day (highest mean of 5.7 Liters/day), depending on its availability. Many farmers in the study area had been trained on proper amount of milk feeding to calves in the past (minimum $4 \mathrm{~L} /$ day), leading to milk feeding that was even higher than the 4 Liters/day recommended for full milk feeding. The researchers had made the ethical decision to not enforce only feeding $2 \mathrm{~L}$ of milk/day to the calves, if the farmers wanted to feed more milk, since these calves were owned by the farmers and feeding more milk was in the best interests of the calf.

It was surprising that the half CSI + half MI group (Group 5) recorded the lowest mean ADG of weights and heights (Figure 4), even though the starter intake was set to maximize at $0.5 \mathrm{~kg}$, and two Liters of milk were paid for per day. It remains unclear why Group 5 had lower ADG of weight than the control CSI groups, which consumed 0.1 to $0.3 \mathrm{~kg} /$ day of CSI on average, compared to Group 5 consuming $0.4 \mathrm{~kg} /$ day on average. In the control groups, farmers followed their normal calf rearing practice with no interference. If the farmer found it costly to feed more milk, it is possible that the farmer could reduce the milk component and focus on the full calf starter, especially since the calf starter was being provided free of charge as part of the study. The low growth rate may be because the half MI and half CSI feed only catered for slightly above calf maintenance requirements and could not meet the requirements for optimal growth. It is also possible that other factors, such as disease incidence (diarrhoea and pneumonia), housing and sex of the calves among other factors, may have been partly responsible for this surprising finding, factors that would likely be more evenly distributed among the groups with a larger study population. It is important to note that this group with the lowest mean weight gain in this trial $(0.29 \mathrm{~kg} /$ day) still had higher ADG $(0.26 \mathrm{~kg} /$ day $)$ than in Kiambu County (Gitau et al., 1994), possibly due to a higher dietary protein content of the half CSI.

Age, body condition score and normal function of the gastrointestinal system of the calves were associated with higher weights in the final regression model that controlled for confounding, as was expected. Absorption and metabolism of nutrients for growth and maintenance requires a healthy and functional gastrointestinal system. Body condition scores normally improve as pre-weaned calves get older, as long as the diet is appropriate and the calves are healthy. Intervention group was not significantly associated with weight in the final regression model, likely because the amount of 
calf starter consumed was significant in the final model.

The final multivariable mixed linear regression model also shows an interaction between feeding sweet potato vines and mineral block. The calves on supplementary diet with sweet potato vines performed better in that they recorded higher overall mean weights. This result is not unexpected because sweet potato leaves contain $17 \%$ protein, which is higher than many grasses (Murugan et al., 2012). Failure to feed sweet potato vines resulted in lower weights among the calves, however with significantly lower weights when a mineral block was provided alongside sweet potato vines. Radostits and Bell (1968) reported that fat digestibility has an effect on nitrogen retention, which in turn influences metabolism of calcium, phosphorus and magnesium, resulting in excretion of faecal fat and increased fecal content of calcium and magnesium, potentially leading to reduced weight gain. Further research is needed to examine how this interaction may be affecting the growth of calves.

The study findings reported disease incidence (pneumonia and diarrhoea) in feed intervention groups 1, 2, 4, 5, 6 and 8. This disease incidence could also have impacted the study results, based on a study by Wenge et al. (2014) that reported a $2.2 \mathrm{lb}$ per day drop in dry matter intake between the day before diarrhoea began and the day diarrhoea starts. However, there was no significant association between calf sickness and weight in the final model, perhaps due to the small number of sick calves and total calves in the study. The final model did show that a normal gastrointestinal tract was associated with a $1.9 \mathrm{~kg}$ higher weight above the median weight. There was no sick calf in group 7, which may partly explain it having the highest ADG and mean weights and heights.

The final multivariable mixed linear regression model also shows an interaction between feeding sweet potato vines and mineral block. The calves on supplementary diet with sweet potato vines performed better in that they recorded higher overall mean weights. This result is not unexpected because sweet potato leaves contain $17 \%$ protein, which is higher than many grasses (Murugan et al., 2012). Failure to feed sweet potato vines resulted in lower weights among the calves, however with significantly lower weights when a mineral block was provided alongside sweet potato vines. Radostits and Bell (1968) reported that fat digestibility has an effect on nitrogen retention, which in turn influences metabolism of calcium, phosphorus and magnesium, resulting in excretion of faecal fat and increased fecal content of calcium and magnesium, potentially leading to reduced weight gain. Further research is needed to examine how this interaction may be affecting the growth of calves.

The study findings reported disease incidence (pneumonia and diarrhoea) in feed intervention groups 1, 2, 4, 5, 6 and 8. This disease incidence could also have impacted the study results, based on a study by Wenge et al. (2014) that reported a $2.2 \mathrm{lb}$ per day drop in dry matter intake between the day before diarrhoea began and the day diarrhoea starts. However, there was no significant association between calf sickness and weight in the final model, perhaps due to the small number of sick calves and total calves in the study. The final model did show that a normal gastrointestinal tract was associated with a $1.9 \mathrm{~kg}$ higher weight above the median weight. There was no sick calf in group 7, which may partly explain it having the highest ADG and mean weights and heights

The small number of calves in this pilot project was a limitation to the generalization of the results of this study, and the ability to find significant factors associated with weights. Another limitation was that it was not possible to fully blind the owners to their feeding group (i.e. they were instructed to feed their group allocation amounts, but could figure out their group allocation if they talked with other study participants feeding different amounts), however the outcomes (weight, height, morbidity and mortality) were assessed blindly.

We wanted to determine factors associated with weekly ADG; however the crude estimations provided by weight tapes were not accurate enough for weekly ADG, leading to negative ADGs in healthy well-fed calves. Overall ADG based on the starting and ending weights provided low power to detect significant associations with the number of observations dropping from 256 to 35 . Therefore, factors associated with weekly weights from the weight tapes was the best option for this objective. 
The milk intake in calves on smallholder dairy farms in Kenya is usually restricted in most farm settings to about two to four Liters per day, with 2 L/day only providing for maintenance and minimal growth requirements of the calf (Drackley, 2008), making ad lib calf starter feeding essential. Even though calf starter intake is reported to increase quickly when milk fed to calves is decreased, weaning of the calf before the rumen is developed enough to efficiently digest the starter and absorb the resulting VFA can result in pronounced slumps in growth (Drackley, 2008).The efficiency of dietary protein use for body protein development is reported to be highest in young calves less than two months of age, and this growth potential decreases with increases in body size (Gerrits et al., 1996; Stamey et al., 2012).

This is the first clinical trial demonstrating the growth benefits of feeding various levels of calf starter and milk in dairy calves on semicommercial smallholder dairy farms in Kenya. The results, although conducted among small numbers due to it being a pilot project, clearly demonstrate the growth benefits of feeding recommended amounts of calf starter, even in the face of varying amounts of milk intake in the controls. In this regard, the results of this study should be considered for implementing feeding and nutrition improvement programs in the smallholder dairy farms.

\section{Conclusions}

The study concluded that there were significant differences between feed intervention groups. Calves on diets containing full allocations of calf starter had higher average daily weight gains (over $0.5 \mathrm{~kg}$ /day) than calves on half or control allocations of calf starter. Group 7 (full calf starter + control milk intake) was superior to the rest of the groups as it recorded the highest weight, height and average daily weight gains, because of the full calf starter allocation and the highest milk consumption (despite it being a control group for milk consumption). The following factors were significantly associated with higher calf weights in the final multivariable model: calf age and body condition score, the calf having a normal gastrointestinal tract, amount of calf starter consumed per day, and feeding sweet potato vines. These findings will help in future management recommendations of calf feeding interventions on smallholder dairy farms.

\section{Acknowledgments}

The authors are grateful to Prince Edward Island University for having extended generous financial assistance towards this project and MWDL and its farmers for the outstanding support given to us while carrying out this study at their farms. Farmers Helping Farmers and Veterinarians without Borders-Canada are two non-governmental organizations in Canada that also provided financial and logistical support for the study.

Fernández, H.T., Busso, C. A.I., Laborde, H.E., Torrea, M.B., Fernández, L.M., López, G.H., Delucchi, F., and García, B.N., (2012). Growth, blood metabolites and hormones in calves fed diets with different amounts of energy and protein during the pre- or post-weaning periods. African Journal of Agricultural Research, 7(25): 3739-3746.

Gerrits, W.J., Tolman, G.H., Schrama, J.W., Tamminga, S., Bosch, M.W., Verstegen, M.W., (1996). Effect of protein and protein-free energy intake on protein and fat deposition rates in pre-ruminant calves of 80 to $240 \quad \mathrm{~kg}$ live weight. Journal of Animal Science. 74(9):2129-2139. 
Gitau, G.K., McDermott, J.J., Adams, J.E., Lissemore, K.D., and Waltner-Toews, D., (1994). Factors influencing calf growth and daily weight gain on smallholder dairy farms in Kiambu district, Kenya. Preventive Veterinary Medicine. 21: 179-190

Kenya National Bureau of Statistics, (2019). Kenya 2019 Population and Housing Census Volume 1B - Population Distribution by Political Units. http://www.knbs.or.ke/index.php?op tion $=$ comphocadownload \&view $=$ categ ory\&id=109:population-and-housingcensus-2009\&Itemid $=599$

Lanyasunya, T.P., Rong, Wang, H., Abdulrazak, S.A., and Mukisira, E.A., (2006). Effect of supplementation on performance of calves on smallholder dairy farms in bahati division of Nakuru district, Kenya. Pakistan Journal of Nutrition 5: 141 -

146. http://www.pjbs.org/pjnonline/f in367.pdf

Laswai, G.H., Lyimo, H.L.N., Mtenga, L.A., Kimambo, A.E., Mgheni, D.M., Hvelplund, T., Madsen, J., and Weisbjerg, M., (2007). Effects of local concentrate and weaning age on the performance of crossbred calves. Journal of Animal and Feed Sciences, 16: 419-423.

Listiari, H., Sutrisno, C.I., Muktiani, A., and Sulistyanto, B., (2015). A survey of preweaning calves practice in smallholder dairy farms in Indonesia. Livestock Research for Rural Development. 27 (90). http://www.lrrd.org/lrrd27/5/h end27090.html

Lyimo, H. L.N., Laswai G. H., Mtenga, L. A., Kimambo, A. E., D. M. Mgheni., T. Hvelplund., M. R. Weisbjerg and J. Madsen. (2010). Performance of crossbred calves raised on different dietary treatments under smallholder dairy farm conditions. Livestock Research for Rural Development. 22 (3)

Makau, D.N, J.A. VanLeeuwen, G.K. Gitau, J. Muraya, S.L. McKenna, C. Walton, and J.J. Wichtel. 2018. Animal and management factors associated with weight gain in dairy calves and heifers on smallholder dairy farms in Kenya. Preventive Veterinary Medicine, 161: 6068.

doi:10.1016/J.PREVETMED.2018.10.017.
Makau, D.N, J.A. VanLeeuwen, G.K. Gitau, S.L. McKenna, C. Walton, J. Muraya, and J.J. Wichtel. 2019. Effects of Calliandra and Sesbania supplementation on weight gain in dairy calves on smallholder farms in Kenya. Preventive Veterinary Medicine, $172 . \quad$ DOI: 10.1016/j.prevetmed.2019.104787

Murugan Sankaran., Suresh Kumar Paramasivam., and Maniyam Nedunchezhiyan., (2012). Sweet Potato as Animal Feed and Fodder. http://www.globalsciencebooks.info/O nline/GSBOnline/images/2012/FVCSB 6(SI1)/FVCSB_6(SI1)106-1140.pdf

Moran, J.B., (2005). Tropical dairy farmingFeeding management for smallholder dairy farmers in the humid tropics. Landlinks Press, Victoria.

Moran, J.B., (2009). Rearing young stock on tropical dairy farms in Asia. CSIRO Publishing.

Njarui, D.M.G., Gatheru, M., Wambua, J.M., Nguluu, S.N., Mwangi, D.M., and Keya, G.A., (2011). Feeding management for dairy cattle in smallholder farming systems of semi-arid tropical Kenya. Livestock Research for Rural Development. $23 \quad$ (111). http://www.lrrd.org//rrd23/5/njar231 11.htm.

Nyka, R., Kessy, B.M., Lyimo, Z.C., Msangi, B.S., Turuka, F., and Mtenga, K., (2014). Constraints on smallholder market oriented dairy systems in the north eastern coastal region of Tanzania. Tropical Animal Health and Production. 39: 627-636.

Odima, P.A., McDermott, J.J., and Mutiga, E.R., (1994). Reproductive performance of dairy cows on smallholder dairy farms in Kiambu District, Kenya: Design, Methodology and Development constraints. Proceedings of the $7^{\text {th }}$ ISVEE Symposium. 15 $15^{\text {th }}-19^{\text {th }}$ August, 1994. Nairobi, Kenya. The Kenya Veterinarian. 18(2): 366.

Oloo, O.B., (2016). Lessons in sustainable dairy farming to Kenyan dairy sector from the Dutch dairy sector. Journal of Advanced Dairy Res. 4(4):162.

Orodho, A.B., (2006). Country Pasture/Forage Resource Profiles Kenya. Rome: FAO. http://www.fao.org/ag/agp/agpc/doc Lcounprof/PDF\%20files/SouthAfrica 
Peter, S.G., Gitau, G.K., Mulei, C.M., Vanleeuwen, J., Richards, S., Wichtel, J., Fabienne, Uehlinger, and Omwando, Mainga., (2015). Prevalence of cryptosporidia, eimeria, giardia, and strongyloides in pre-weaned calves on smallholder dairy farms in Mukurwe-ini district, Kenya. Veterinary World. 8(9): 1118-1125.

Peter, S.G., Gitau, G.K., Richards, S., Vanleeuwen, J.A., Uehlinger, F., Mulei, C.M., and Kibet, R.R., (2016). Risk factors associated with Cryptosporidia, Eimeria and diarrhea in smallholder dairy farms in Mukurwe-ini Sub-County, Nyeri County-Kenya. Veterinary World. 9 (8): 811-819.

Radostits, O. M. and Bell, J. M., (1968). Nutrient digestibility by new-born calves fed milk replacer. Canadian Journal of Animal Science. 4E: 293-302.

Richards, S., VanLeeuwen, J., Shepelo, G., Gitau, G.K., Collins, C.K., Uehlinger, F., and Wichtel, J., (2015). Associations of farm management practices with annual milk sales so smallholder dairy farms in Kenya. Veterinary World. 8: 88-96.

Stamey, J.A., Janovick, N.A., Kertz, A.F., and Drackley, J.K., (2012). Influence of starter protein content on growth of dairy calves in an enhanced early nutrition program. Journal of Dairy Science. 95: 3327-3336.
Tiwari, R., Sharma, M.C., and Singh, S.P., (2007). Buffalo calf health care in commercial dairy farms: a field study in Uttar Pradesh (India). Livestock Research for Rural Development. 19(3). http://www.lrrd.org/lrrd19/3/ti wa19038.htm

VanLeeuwen, J.A., Mellish, T., Walton, C., Kanaru, A., Gitau, R., Mellish, K., Maina, B., and Wichtel, J., (2012). Management, productivity and livelihood effects on Kenyan smallholder dairy farms from interventions addressing animal health and nutrition and milk quality. Tropical Animal Health and Production. 44: 231238.

Wambugu, S., Kirimi, L., and Opiyo, J., (2011). Productivity trends and performance of dairy cows in Kenya. Tegemeo Institute of Agriculture Policy and Development. Nairobi, Kenya. http://www.tegemeo.org/images/dow nloads/Working\%20papers/WP43Productivity-Trends and-Performanceof-Dairy-Farming-in.pdf.

Wenge, J., I. Steinhöfel, C. Heinrich, M. Coenen, and L. Bachmann L. (2014). Water and concentrate intake, weight gain and duration of diarrhea in young suckling calves on different diets. Livestock Science. 159:133-144. 